\title{
The Involvement of Ser 1898 of the Human L-Type Calcium Channel in Evoked Secretion
}

\author{
Niv Bachnoff, Moshe Cohen-Kutner, and Daphne Atlas \\ Department of Biological Chemistry, The Alexander Silberman Institute of Life Sciences, The Hebrew University of Jerusalem, \\ Jerusalem 919104, Israel \\ Correspondence should be addressed to Daphne Atlas, datlas@vms.huji.ac.il
}

Received 3 July 2011; Accepted 17 August 2011

Academic Editor: Maria L. Dufau

Copyright ( $\odot 2011$ Niv Bachnoff et al. This is an open access article distributed under the Creative Commons Attribution License, which permits unrestricted use, distribution, and reproduction in any medium, provided the original work is properly cited.

\begin{abstract}
A PKA consensus phosphorylation site S1928 at the $\alpha_{1} 1.2$ subunit of the rabbit cardiac L-type channel, Cav 1.2 , is involved in the regulation of $\mathrm{Ca}_{V} 1.2$ kinetics and affects catecholamine secretion. This mutation does not alter basal $\mathrm{Ca}_{V} 1.2$ current properties or regulation of $\mathrm{Ca}_{V} 1.2$ current by PKA and the beta-adrenergic receptor, but abolishes Cav 1.2 phosphorylation by PKA. Here, we test the contribution of the corresponding PKA phosphorylation site of the human $\alpha_{1} 1.2$ subunit S1898, to the regulation of catecholamine secretion in bovine chromaffin cells. Chromaffin cells were infected with a Semliki-Forest viral vector containing either the human wt or a mutated S1898A $\alpha_{1} 1.2$ subunit. Both subunits harbor a T1036Y mutation conferring nifedipine insensitivity. Secretion evoked by depolarization in the presence of nifedipine was monitored by amperometry. Depolarizationtriggered secretion in cells infected with either the wt $\alpha_{1} 1.2$ or $\alpha_{1} 1.2 / \mathrm{S} 1898 \mathrm{~A}$ mutated subunit was elevated to a similar extent by forskolin. Forskolin, known to directly activate adenylyl-cyclase, increased the rate of secretion in a manner that is largely independent of the presence of S1898. Our results are consistent with the involvement of additional PKA regulatory site(s) at the C-tail of $\alpha_{1} 1.2$, the pore forming subunit of $\mathrm{Ca}_{V} 1.2$.
\end{abstract}

\section{Introduction}

The voltage-gated calcium channels (VGCCs) are regulated by kinases that are activated by second messenger pathways [1-4]. The dihydropyridine-sensitive VGCC, known as the L-type channel or Cav1.2, is modulated by protein kinase A (PKA) and protein kinase C (PKC) [4]. The $\beta$-adrenergic receptor activates cAMP-dependent phosphorylation by PKA, which increases the amplitude of voltage-dependent $\mathrm{Ca}^{2+}$ currents. It is now well established that the $\beta$-adrenergic signaling enhances inward $\mathrm{Ca}^{2+}$ currents via $\mathrm{Ca}_{\mathrm{V}} 1.2$ phosphorylation in cardiac myocytes [2, 4-6], adrenal chromaffin cells $[7,8]$, rat hippocampal neurons [9] and in skeletal muscle [10].

PKA phosphorylation of the L-type channel leads to an increase in the open probability $\left(P_{o}\right)$ of the channel [5] and an increase in the mean open time by augmenting the number of long openings [11]. In the heart activation of the $\beta$-adrenergic signaling pathways increases calcium currents $\sim 4$ fold and is attributed to the phosphorylation of Cav 1.2 [12].
The L-type channel assembles with Gs, adenylyl cyclase, PKA, and phosphatase PP2A into a signaling complex that enables the rapid modulation of the channel by the adrenergic receptor [13]. Biochemical studies in the heart have shown that the distal C-terminal tail of the $\alpha_{1} 1.2$ subunit is phosphorylated by PKA on serine 1928 (S1928) [14-17]. Phosphorylation of S1928 in cardiac and neuronal cells implies $\beta$-adrenergic regulation of $\mathrm{Ca}_{v} 1.2[4,17-21]$.

The phosphorylation of S1928, the PKA consensus phosphorylation site at the $\alpha_{1} 1.2$ pore forming subunit of rabbit $\mathrm{Ca}_{V} 1.2$ that is phosphorylated both in vitro and in vivo, was suggested to be responsible for the increase in $\mathrm{Ca}^{2+}$ currents [19].

Additional phosphorylation sites that can also participate in the $\beta$-adrenergic regulation of cardiac L-type $\mathrm{Ca}^{2+}$ channels [16] include the intracellular $\beta$-subunit of the channel $[22,23]$. Since S1928 is phosphorylated also by PKC, it was suggested that both PKA and PKC signaling pathways converge at $S 1928$ of the $\alpha_{1} 1.2$ subunit to increase channel activity [24]. 
More recently, the regulation of $\mathrm{Ca}_{\mathrm{V}} 1.2$ by the $\beta$-adrenergic pathway in mouse heart was tested in vivo using knock-in mouse with a targeted mutation of S1928 to alanine [25]. This mutation, which abolished PKA phosphorylation of S1928, did not affect the kinetic characteristics and the $\beta$ adrenergic regulation of the L-type current. The conclusion led to the suggestion that PKA phosphorylation of S1928 in cardiomyocytes is functionally not involved in the $\beta$-adrenergic stimulation of $\mathrm{Ca}_{\mathrm{V}}$ 1.2-mediated calcium influx [25].

In neuroendocrine cells such as bovine chromaffin and PC12 cells, membrane depolarization triggers catecholamine (CA) secretion primarily by the opening of the L-type channels [26-28]. In these cells, the channel is an integral part of the signaling complex that triggers secretion [29-32]. Voltage-driven perturbations of a $\mathrm{Ca}^{2+}$-bound channel were suggested to transmit the signal from the channel to the exocytotic machinery and trigger fast release of vesicles assembled with the channel [28, 31, 33-35]. Therefore, channel phosphorylation would be expected to modify secretion. As previously shown, inhibitors of protein phosphorylation or injection of phosphatase $2 \mathrm{~A}$ into cells suppresses facilitation of depolarization-evoked secretion [7]. Based on these results it was suggested that facilitation is mediated by phosphorylation of voltage-dependent L-type $\mathrm{Ca}^{2+}$ channel [8].

We examined the modulation of L-type channel and its role in mediating evoked secretion using forskolin. Secretion was triggered in cells infected with the human wt $\alpha_{1} 1.2$ (Hu/wt) or $\alpha_{1} 1.2 / \mathrm{S} 1898 \mathrm{~A}$ ( $\left.\mathrm{Hu} / \mathrm{S} 1898 \mathrm{~A}\right)$ mutant subunit. The S1898 site corresponds to S1928 of rabbit cardiac cells. The frequency of the secretory events mediated by $\mathrm{Hu} / \mathrm{S} 1898 \mathrm{~A}$ and $\mathrm{Hu} / \mathrm{wt}$-infected cells was accelerated by forskolin to a similar extent, indicating that mutating serine 1898 to alanine did not affect the forskolin-induced increase of catecholamine secretion.

Overall, our results suggest that additional PKA-sensitive phosphorylation sites contribute to the PKA modulation of catecholamine release.

\section{Experimental Procedures}

2.1. Materials and Methods. The complete human cDNAs of $\alpha_{1} 1.2$ subunit, accession number AJ224873, rabbit $\beta 2 \mathrm{~b}$ accession number X64298, and rabbit $\alpha 2 / \delta$ accession number NM_001082276, were kindly donated by Dr. M. Sanguinetti (University of Utah). A modified pSFV1 (Invitrogen) plasmid, where an internal ribosome entry site from poliovirus had been inserted followed by the gene for enhanced GFP, was provided by Dr. U. Ashery.

Mutagenesis. Standard methods of plasmid DNA preparation were used to prepare the human $\alpha_{1} 1.2 / \mathrm{S} 1989 \mathrm{~A}$. The $\mathrm{Ca}_{V} 1.2 \alpha_{1}$ subunit coding sequence (AJ224873) was used as a template. The S1898A mutation was introduced by mutating the codon TCC to GCC by using the Bio-X-Act Long DNA Polymerase kit (Bioline, Israel) and Quick-change site-directed mutagenesis PCR was applied (Bioline, Israel). The following primers were used: 5' -TGCCTCACTAGGTCGAAGGGCCGCCTTCCACCTGGAATGTCTGAA and the $3^{\prime}$-TTCAGACATTCCAGGTGGAAGGCGGCCCTTCGACCTAGTGAGGCA. For amperometry studies, plasmids $\alpha_{1} 1.2 / \mathrm{T} 1036 \mathrm{Y}$ and $\alpha_{1} 1.2 / \mathrm{S} 1898 / \mathrm{T} 1036 \mathrm{Y}$ were inserted upstream of the internal ribosome entry site using BamHI and BssHII restriction sites. All constructs were verified by DNA sequencing and restriction site mapping.

2.1.1. Chromaffin Cell Preparation and Culture. Bovine adrenal glands were obtained at a local slaughterhouse. The adrenal medulla cells were isolated as previously described in [34] and plated at a density of $5 \times 10^{4}$ cells $/ \mathrm{cm}^{2}$ on glass cover slips placed in $35 \mathrm{~mm}$ plates, in DMEM (Gibco) supplemented with ITS-X (Sigma, Israel). Cells were incubated at $37^{\circ} \mathrm{C}$ in $5 \% \mathrm{CO}_{2}$ and were used for amperometric recordings 1-4 days after preparation at $23^{\circ} \mathrm{C}$.

\subsubsection{Amperometric Recordings of Catecholamine Release from} Chromaffin Cell. Amperometry recordings were carried out using $5 \mu \mathrm{m}$ thin carbon fiber electrodes (CFE ALA Incorp. Westbury, NY, USA) and a VA-10 amplifier (NPI-electronic, Tamm, Germany) held at $800 \mathrm{mV}$ as described previously [36]. Cells were rinsed 4 times prior to the experiment and bathed during the recordings at $23^{\circ} \mathrm{C}$ in isoosmotic physiological solution ( $149 \mathrm{mM} \mathrm{NaCl}, 2 \mathrm{mM} \mathrm{KCl}, 1 \mathrm{mM} \mathrm{MgCl}$, $2 \mathrm{mM} \mathrm{CaCl}_{2}, 10 \mathrm{mM}$ Glucose, and $10 \mathrm{mM}$ HEPES, pH 7.3 at $\sim 23^{\circ} \mathrm{C}$ (adjusted with $\left.\mathrm{NaOH}\right)$ ). Individual cells were stimulated to release by a $10 \mathrm{sec}$ application of isoosmotic $60 \mathrm{mM}$ $\mathrm{KCl}$ buffer from a $\sim 3 \mu \mathrm{m}$ tipped micropipette placed 5-7 $\mu \mathrm{m}$ from the cell in the bath. Amperometric currents were sampled at $10 \mathrm{kHz}$, using clampex 9.2 (Axon Instruments) and low-pass filter at $1 \mathrm{kHz}$.

Secretion of catecholamines from fluorescent cells identified at $480 \mathrm{~nm}$ excitation was recorded 16-24 hrs after infection by amperometry.

\subsection{3. pSFV Infection}

Virus Preparation and Infection. Recombinant SFV particles were generated as described previously in [37]. Briefly, in vitro transcribed RNA from pSFV-GFP, or pSFV expressing GFP through an internal ribosome entry site (IRES) motif, pSFV-Nifedipine-insensitive $\alpha_{1} 1.2$-IRES-GFP, or pSFV-Nifedipine-insensitive $\alpha_{1} 1.2 /$ S1898A-IRES-GFP was coelectroporated into BHK-21 cells with pSFV-Helper-2 RNA. Virus stocks were harvested $24 \mathrm{hr}$ later and activated with alpha-chymotrypsin before infection studies. Approximate titers were estimated by infection of known numbers of BHK-21 cells with serial dilutions of SFV stocks, and the GFP-positive cells were counted. Generally, titers in the range of $5 \times 10^{8}$ infectious particles $/ \mathrm{mL}$ were obtained.

SFV particles $(30 \mu \mathrm{L} /$ dish $)$ were added to the cultured cells $\left(2 \times 10^{5}\right.$ cells per dish $) 5-48 \mathrm{~h}$ after plating. Infected cells were identified by their GFP fluorescence.

2.1.4. Amperometric Data Acquisition and Analysis. Rates of secretion were determined for individual cells and averaged. Spike frequencies were quantified for individual cells by the slopes of the cumulative events during $10 \mathrm{sec}$ of $\mathrm{KCl}$ 
stimulation and a $20 \mathrm{sec}$ poststimulus period $(10-40 \mathrm{sec})$ and were averaged to obtain a cell mean. The rate of secretion during 10-40 sec was determined from the slopes of the corresponding cumulative spike plots. Data was analyzed as described in the text and figure legends. Error bars give standard errors. Spikes exceeding three times the background noise $(>10 \mathrm{pA})$ were analyzed. All peaks identified by the program IGOR PRO (Wavemetrics, Lake Oswego, Or, USA) were inspected visually and bad signals were excluded manually.

\subsubsection{Expression in Xenopus Oocytes and cRNA Injection.} Stage V-VI Xenopus laevis oocytes were removed surgically from the ovaries of anesthetized animals and transferred to a $\mathrm{Ca}^{2+}$-free medium $(96 \mathrm{mM} \mathrm{NaCl}, 2 \mathrm{mM} \mathrm{KCl}, 1 \mathrm{mM} \mathrm{MgCl}$, and $5 \mathrm{mM}$ HEPES, pH7.4) containing $1 \mathrm{mg} / \mathrm{mL}$ collagenase (253 U/mg) (Wortington Bioche. Corp. USA). The follicular cell layer was removed by shaking the oocytes in this buffer for $1.5-2 \mathrm{hr}$ at room temperature. After extensive wash, the oocytes were transferred to ND96 buffer $(96 \mathrm{mM} \mathrm{NaCl}$, $3 \mathrm{mM} \mathrm{KCl}, 1 \mathrm{mM} \mathrm{MgCl}_{2}, 1.8 \mathrm{mM} \mathrm{CaCl}_{2}$, and $5 \mathrm{mM}$ HEPES, $\mathrm{pH} 7.4$ ) containing $2.5 \mathrm{mM}$ pyruvate, $100 \mathrm{U} / \mathrm{mL}$ penicillin, and $10 \mu \mathrm{g} / \mathrm{mL}$ streptomycin. Oocytes were incubated in ND96 for $12-20 \mathrm{hr}$ before cRNA injection.

2.1.6. cRNA Injection into Oocytes and Electrophysiology. cRNAs were prepared using the T7 Fermentas transcription kit (Lituania), and the product was monitored by gel electrophoresis and optical density measurements. In vitro transcribed capped cRNA of the channel subunits were injected into the defolliculated oocytes in a final volume of $40 \mathrm{~nL}$ using a Drummond 510 microinjector (Broomall, Pa, USA). Oocytes were maintained at $18^{\circ} \mathrm{C}$ for 5 days after injection [30].

2.1.7. Confocal Imaging. Single optical sections through the oocytes were obtained with an Olympus FV1000 (Olympus, Japan) equipped with a $40 \mathrm{x}$ oil objective (N.A. 1.3). Two excitation lasers were used sequentially: $488 \mathrm{~nm}$ GFP and narrow-band emission filters $505-525 \mathrm{~nm}$. Sequential scanning was performed with a resolution set to $512 \times 512$ pixels $(0.621 \mathrm{~mm} / \mathrm{pixel})$, and single optical sections $\sim 0.5 \mu \mathrm{m}$ thick were captured. Exposure time was $8 \mu \mathrm{sec} /$ pixel.

\section{Results}

3.1. Mutated $\alpha_{1}$ Subunit Is Targeted to the Cell Membrane. The sequence homology of the phosphorylation consensus site of S1928 at the distal C-terminal of the $\alpha_{1} 1.2$ pore forming subunit corresponds to S1898 in the human $\alpha_{1} 1.2$, as shown in Figure 1(a). This highly conserved sequence in various species represents a PKA consensus phosphorylation motif (Figure 1(b)).

The consensus $\mathrm{S} 1898$ of the human $\alpha_{1} 1.2$ subunit was mutated to Ala and inserted into a frog expression vector. The cRNAs encoding the GFP-tagged human $\alpha_{1} 1.2$ subunit of Cav 1.2 or the GFP- $\alpha_{1} 1.2 /$ S1898A mutant were coinjected into oocytes along with the cRNAs encoding the auxiliary rabbit $\alpha 2 \delta$ and $\beta 2$ b channel subunits (see Section 2). Oocytes

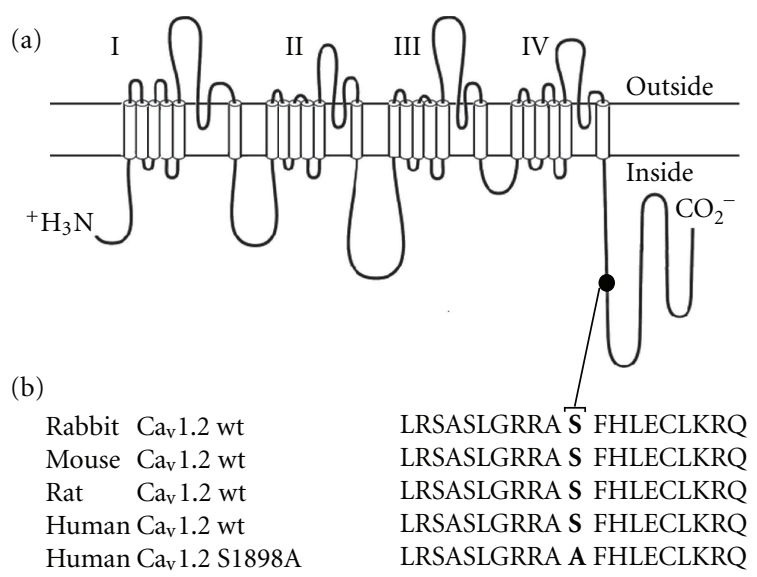

(c)
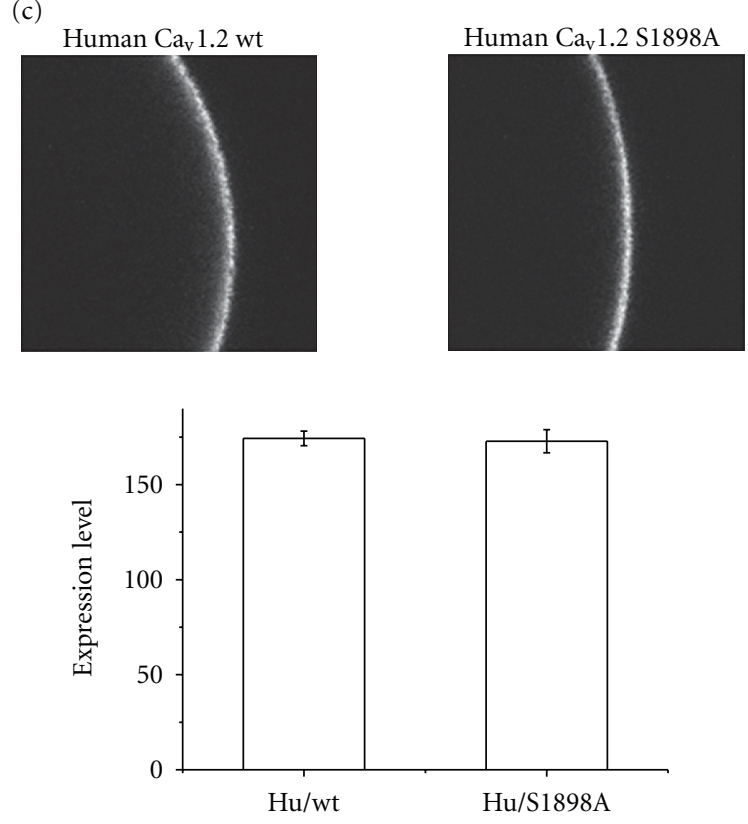

Figure 1: Membrane targeting of $\alpha_{1} 1.2$ and $\alpha_{1} 1.2 / \mathrm{S} 1898 \mathrm{~A}$ to the membrane. (a) Schematic view of the $\alpha_{1} 1.2$ pore forming subunit of $\mathrm{Ca}_{\mathrm{V}}$ 1.2. (b) A comparison of the protein kinase A (PKA) consensus sequence of the highly conserved Ser located at the distal C-terminal of $\alpha_{1} 1.2$ of various species. (c) The human GFP- $\alpha_{1} 1.2$ ( $7 \mathrm{ng} /$ oocyte) and the GFP- $\alpha_{1} 1.2 / \mathrm{S} 1898 \mathrm{~A}$ ( $7 \mathrm{ng} /$ oocyte) were injected into Xenopus laevis oocytes together with the $\beta 2 \mathrm{~b}$ ( $2.5 \mathrm{ng} /$ oocyte) and $\alpha 2 \delta$ ( $5 \mathrm{ng} /$ oocyte). Five days later the oocytes were imaged by confocal microscopy. Membrane targeting and expression of the channels to the membrane were determined by calculating the pixel/area.

imaged by confocal microscopy showed a similar mean gray value for both channels, indicating nearly identical level of protein expression and targeting to the membrane (Figure 1(c)).

3.2. Depolarization-Induced Secretion in Bovine Chromaffin Cells Is Largely Mediated by CaV 1.2 and Is Not Affected by the Viral Infection. Modulation of catecholamine secretion mediated by human $\alpha_{1} 1.2$ subunit was tested in bovine chromaffin cells. 
At first, using a selective $\mathrm{Ca}_{\mathrm{v}} 1$ channel blocker, we confirmed that depolarization-evoked release is mediated primarily by the L-type channel (Figure 2(a)). The evoked release was significantly inhibited by $5 \mu \mathrm{m}$ nifedipine present in the bath (Figure 2(a) inset). Averaged time courses of exocytosis in the absence and in the presence of $5 \mu \mathrm{M}$ nifedipine are shown by the cumulative histograms (Figure 2(a), upper right). Spike frequencies were quantified for individual cells as initial rates, which correspond to the linear fits to the averaged cumulative histograms (bold lines) collected from cells $(n=49)$ during the $10 \mathrm{sec}$ of $60 \mathrm{mM} \mathrm{KCl} \mathrm{(K60)} \mathrm{stim-}$ ulation and a $20 \mathrm{sec}$ poststimulus period (range 10-40 sec) (Figure 2(a), lower right).

We then tested the effect of Semliki Forest virus (SFV) infection on the rate of secretion in cells using SFV viral vector harboring GFP, as previously described [28]. The infected fluorescent cells that were visualized using UV detection were depolarized by K60 for $10 \mathrm{sec}$ and catecholamine release was monitored as amperometric spikes using carbon fiber electrode, where each spike represents the release of a single vesicle $[36,38]$. Secretion from the fluorescent cells was monitored 16-24 hrs after infection. The extent of release was hardly affected by the infection procedure as seen in the amperometric traces (Figure 2(b)) consistent with previous studies $[28,37]$. Evoked secretion was significantly decreased in the presence of nifedipine, in GFP-infected cells, similarly to noninfected cells (Figure 2(b) inset). The overall time course of secretion determined from the normalized waiting time distributions was 0.52 spike/sec in the GFP-infected cells (Figure 2(b), lower) and 0.53 spike/sec in noninfected cells (Figure 2(a), lower). No release was detected when the cells were stimulated in a $\mathrm{Ca}^{2+}$-free solution (Figure 2(c), left) or in the absence of K60 (Figure 2(c), right).

\subsection{The Kinetic Parameters of Amperometric Spikes and Foot} in Cells Infected with GFP- and the wt Human $\alpha_{1} 1.2(\mathrm{Hu} / w t)$. To study secretion mediated by the human channel, we created a pSFV vector expressing wt $\alpha_{1} 1.2$ human channel subunit $(\mathrm{Hu} / \mathrm{wt})$. As a control we monitored the kinetics of secretion induced in cells that were infected with $\mathrm{pSFV}$ vector expressing GFP (see above). Secretion mediated by the wt $\alpha_{1} 1.2(\mathrm{Hu} / \mathrm{wt}) \mathrm{pSFV}$ vector was monitored in the presence of $5 \mu \mathrm{M}$ nifedipine. The nifedipine insensitivity was used to distinguish between the endogenous cellular channels and our cloned channels that were made resistant to nifedipine (Nif) by a single-amino-acid mutation, T1036Y [39]. The T1036Y mutation rendered the channels completely impermeable to calcium ions as previously shown in HEK 293 cells and in Xenopus oocytes $[28,39]$. Differences between the spike and pre-spikes (foot) kinetics elicited in GFP-infected and the Hu/wt-infected cells indicate differences between bovine and human $\mathrm{Ca}_{\mathrm{V}}$ 1.2. Representative amperometric spikes elicited by a $10 \mathrm{sec}$ pulse of K60 from single GFP- and in Hu/wt-infected cells are shown in Figure 3(a). The kinetic parameters of amperometric currents, including peak amplitude, half-width, $50-90 \%$ rise time, and integrated spike $(Q$, gray area) as well as foot width, foot amplitude, and integrated foot $(Q$, white area), are presented schematically in Figure 3(b). The amperometric currents were quantified analyzing the distribution of the data depicted as cumulative probability in the GFP and the Hu/wt channel subunit (Figures 3(c)-3(f)). For every parameter, the values from each cell were averaged and presented as the mean of cell averages \pm the standard error of the mean (SEM) for each group [40]. The kinetic parameters of spikes including spike amplitude, 50-90\% rise time, and mean-charge, were similar while the spike half-width was slightly higher in $\mathrm{Hu} / \mathrm{wt}$ (Figures 3(e) and 3(f)).

The foot amplitude and the kinetics of foot width were not significantly different, calculated by analyzing the distribution of the data and depicted as cumulative probability in the GFP- and the Hu/wt-infected cells (Figures 3(g) and $3(\mathrm{~h})$ ).

3.4. The Kinetic Parameters of Amperometric Spike and Foot Elicited by Human wt and Mutated S1898A Channels. The $\alpha_{1} 1.2(\mathrm{Hu} / \mathrm{wt})$ or the $\alpha_{1} 1.2 / \mathrm{S} 1898 \mathrm{~A}(\mathrm{Hu} / \mathrm{S} 18989 \mathrm{~A})$ subunits that harbored a second mutation T1036Y that rendered the channel nifedipine insensitive were subcloned into a pSFV, which expresses GFP through an internal ribosome entry site (IRES) motif [28]. Both Hu/wt and the mutated Hu/S1898A subunits, which included GFP, were made dihydropyridine insensitive and enabled discrimination of secretion mediated by exogenously expressed human channels from that of native bovine calcium channels $[28,39]$. We tested the kinetic parameters of cells infected with either Hu/wt or Hu/S1898A subunits in the presence of $5 \mu \mathrm{M}$ nifedipine, 16-24 hrs after infection as shown by representative amperometric currents (Figures 4(a) and 4(b)). The amperometric spikes elicited in the $\mathrm{Hu} / \mathrm{wt}$, and $\mathrm{Hu} / \mathrm{S} 1898 \mathrm{~A}$-infected cells were quantified by analyzing the distribution of the data, depicted as cumulative probability (Figures $4(\mathrm{c})-4(\mathrm{f})$; see also Figure 3 ). For every parameter, the values from each cell were averaged and presented as the mean of cell averages \pm the standard error of the mean (SEM) for each group [40]. The mutation of Ser 1898 to Ala, which prevents the phosphorylation at this site, enabled the examination of the net effect of this site on the kinetics of spike and foot parameters. The mutation did not affect spike and foot kinetics as shown by the mean distribution of peak amplitude, half-width, charge, or 50-90\% rise-time (Figures 4(c)-4(f)).

In addition, foot values that correspond to the pre-spike signal and depict the properties of the fusion pore [41] did not show any significant changes in the mean distribution of the cumulative events (Figures $4(\mathrm{~g})$ and $4(\mathrm{~h})$ ).

3.5. Forskolin Increases the Rate of Secretion. It has previously been shown that S1928 is phosphorylated by PKA, both in vitro and in vivo, either directly by $\beta$-adrenergic agonists or indirectly by forskolin [14, 15].

To gain insight into the specific contribution of the corresponding consensus PKA site S1898 to the regulation of catecholamine release mediated via $\mathrm{Ca}_{\mathrm{V}} 1.2$, we applied forskolin to cells infected with $\mathrm{Hu} / \mathrm{wt}$ and $\mathrm{Hu} / \mathrm{S} 1898 \mathrm{~A}$.

The effect of forskolin on secretion was tested at first, on GFP-infected cells. As shown by the amperometric currents 

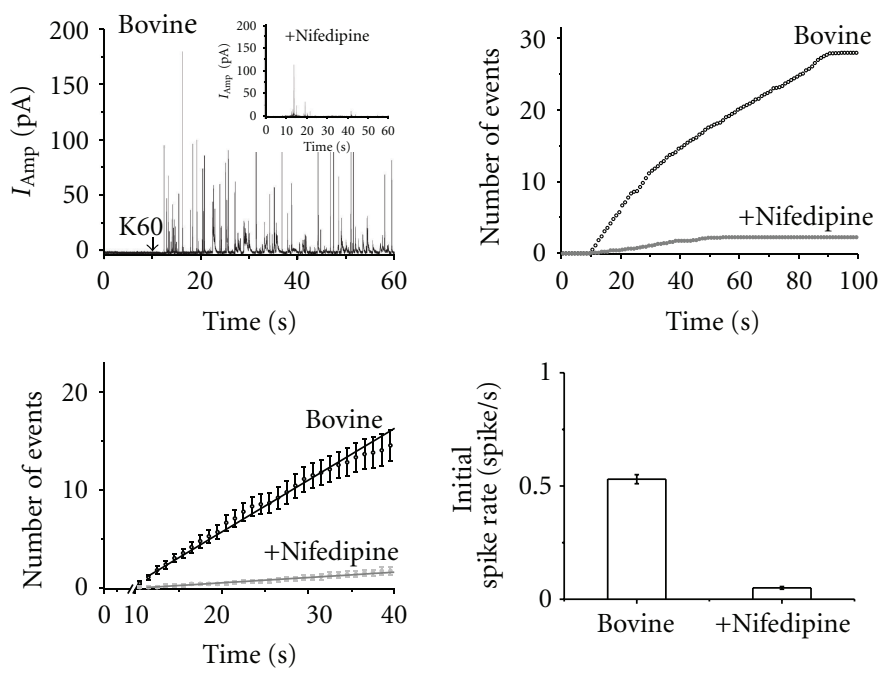

(a)
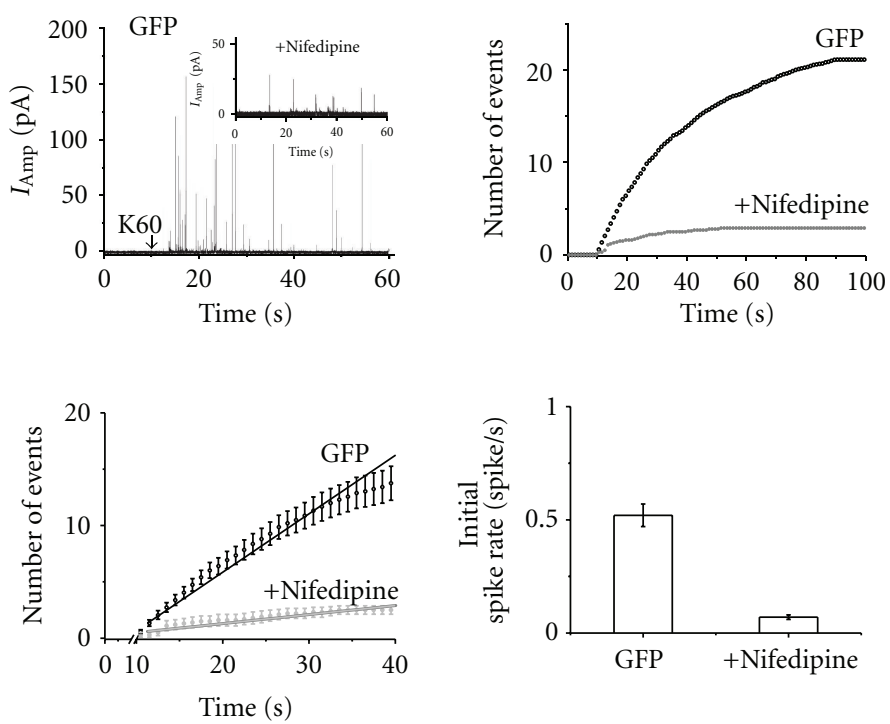

(b)
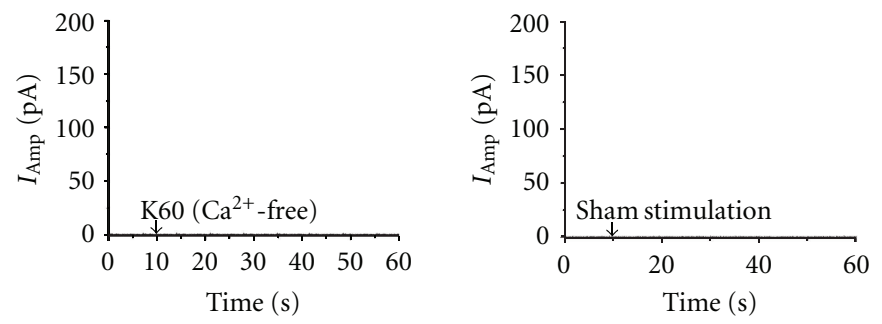

(c)

FIGURE 2: Amperometry measurements of catecholamine release in bovine chromaffin cells. (a) Traces of amperometry currents elicited in noninfected chromaffin cells by a $10 \mathrm{sec}$ puff of $60 \mathrm{mM} \mathrm{KCl} \mathrm{(K60)} \mathrm{as} \mathrm{indicated} \mathrm{by} \mathrm{the} \mathrm{arrow} \mathrm{(left),} \mathrm{and} \mathrm{in} \mathrm{the} \mathrm{presence} \mathrm{of} 5 \mu \mathrm{M}$ nifedipine (inset). The cumulative number of events per cell $(n=18)$, averaged with and without $5 \mu \mathrm{M}$ nifedipine, was plotted versus time (right). An expanded view of the initial cumulative spike counts (lower, left) and the initial rate of secretion calculated from the linearization of the cumulative averaged spike count $(0.53 \pm 0.02$ spike/sec; lower, right $)$. (b) Traces of amperometry currents elicited by a 10 sec puff of $60 \mathrm{mM}$ $\mathrm{KCl}(\mathrm{K} 60)$ in cells infected with pSFV containing GFP (left) and in the presence of $5 \mu \mathrm{M}$ nifedipine (inset). The cumulative number of events per cell was averaged $(n=49)$ with and without $5 \mu \mathrm{M}$ nifedipine and plotted versus time (right). An expanded view of the initial cumulative spike counts (lower, left) and the initial rate of secretion calculated from the linearization of the cumulative averaged spike count $(0.52 \pm$ 0.01 spike/sec; lower, right). (c) Bovine chromaffin cells stimulated under the same experimental conditions as above in nominally Ca ${ }^{2+}$ free solution (left) or stimulated with isoosmotic solution containing $2 \mathrm{mM} \mathrm{KCl}$ a sham stimulation (right). 


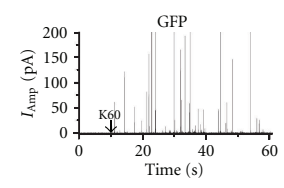

(a)

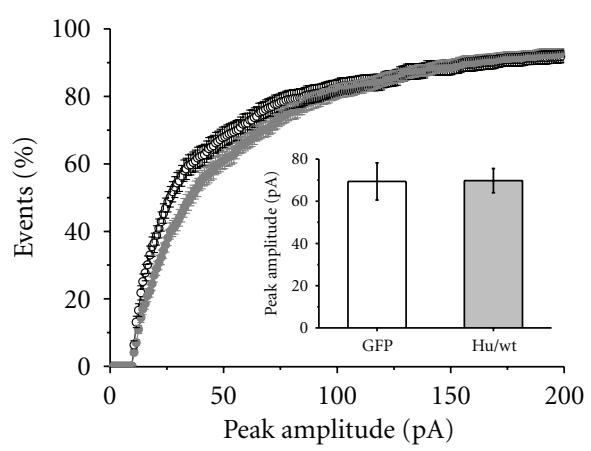

(c)

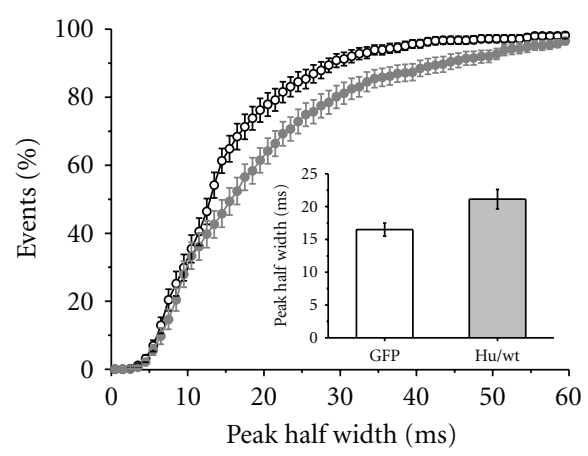

(e)

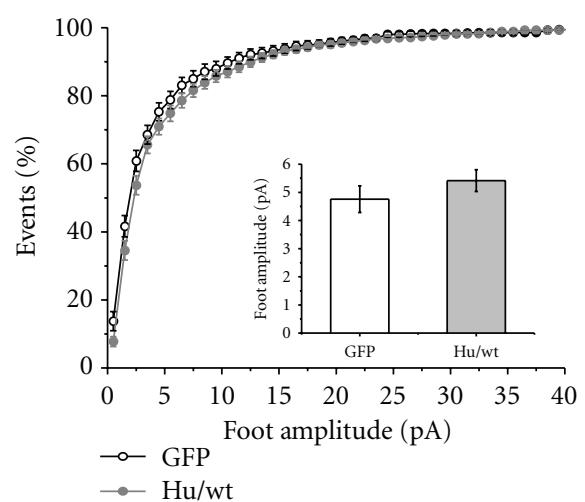

(g)

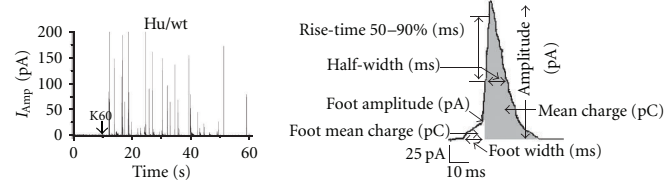

(b)

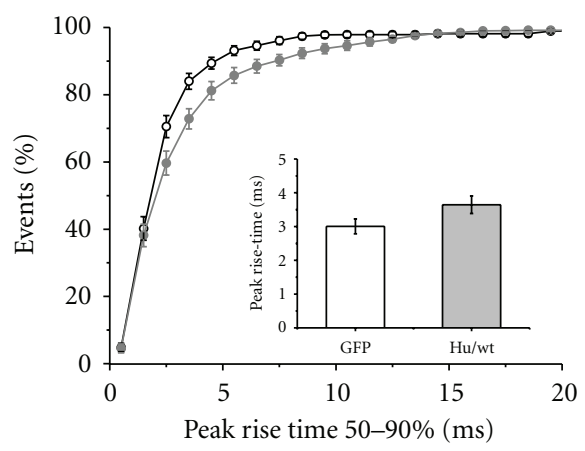

(d)

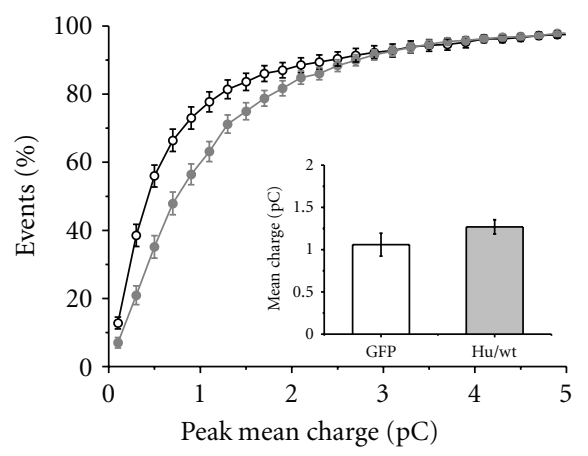

(f)

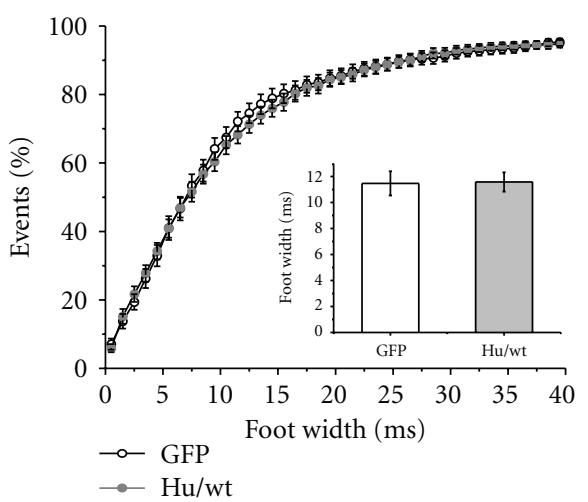

(h)

Figure 3: The kinetics of spike and foot parameters elicited in GFP- and human-wt $\alpha_{1} 1.2$-(Hu/wt-) infected cells are similar. (a) Amperometric currents representing single-vesicle events were triggered by a $10 \mathrm{sec}$ pulse of K60 in cells infected with pSFV containing GFP or $\mathrm{Hu} / \mathrm{wt}$ in the presence of $5 \mu \mathrm{M}$ nifedipine. (b) The kinetic properties of a single amperometric event: peak amplitude, half-width, 50-90\% rise time, and integrated spike (Q, grayarea). Foot signal: foot-width, foot-amplitude, and integrated foot $(Q$, whitearea). (c) Cumulative distribution plots of spike number and analysis of peak amplitude induced in GFP- or Hu/wt-infected cell; (inset), mean values for peak amplitude $n=1048, n=943$ events per data point, respectively. (d) Cumulative distribution plot of spike number and analysis of 50-90\% rise time detected in GFP- and Hu/wt-infected cells. Data plotted in a similar fashion as in (c); mean values for 50-90\% rise time (inset). (e) Cumulative distribution plot of spike number and analysis of half-width in GFP- or Hu/wt-infected cells (inset), mean values for spike halfwidth (f) Cumulative distribution plot of spike number and analysis of mean charge in GFP- or Hu/wt infected cells; (inset), mean values for spike mean charge. (g) Cumulative distribution plot of foot number and analysis of foot amplitude in GFP- or Hu/wt-infected cells (inset), mean values for foot amplitude. (h) Cumulative distribution plot of foot number and analysis of foot width in GFP- or Hu/wt-infected cells (inset), mean values for foot width ${ }^{*} P<0.05$. 


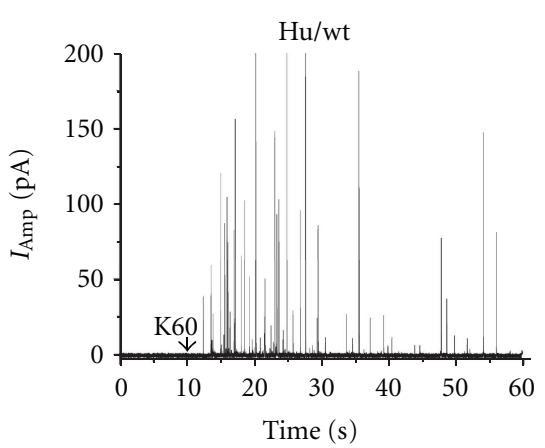

(a)

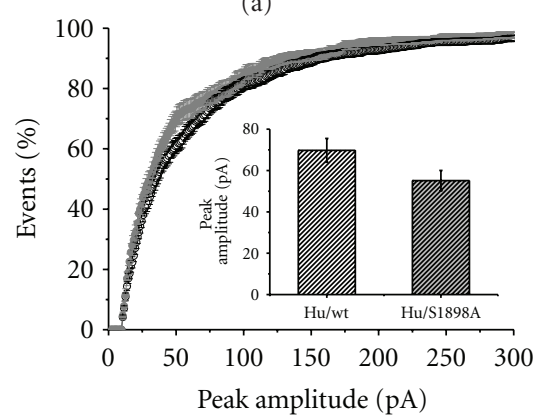

(c)

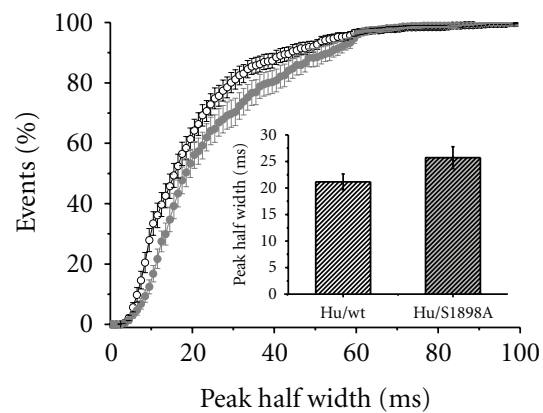

(e)

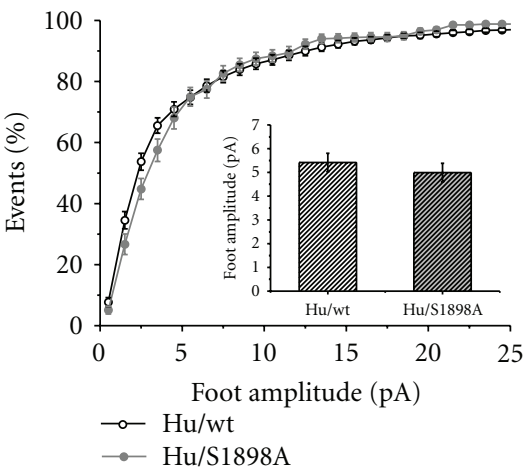

(g)

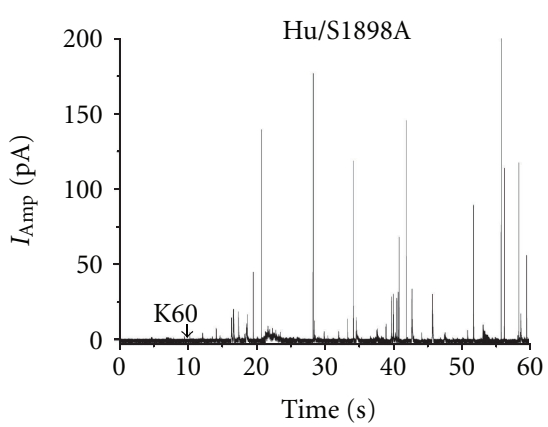

(b)

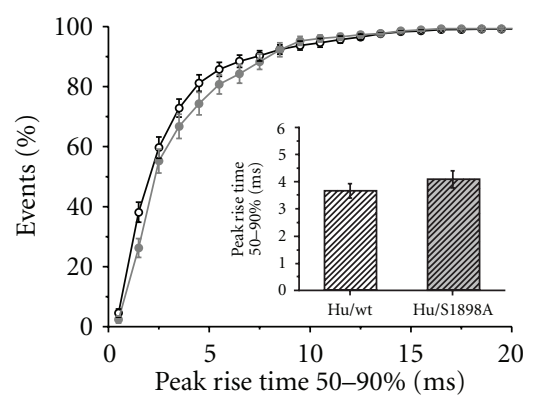

(d)

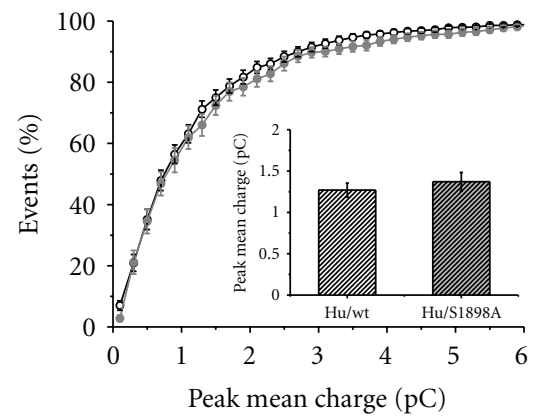

(f)

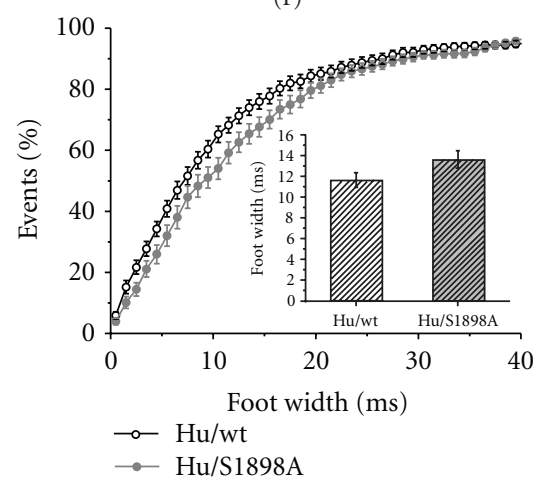

(h)

FIGURE 4: Spike and foot parameters of $\mathrm{Hu} / \mathrm{wt}$ are not affected by the S1898A mutation. Amperometric current triggered in the presence of $5 \mu \mathrm{M}$ nifedipine by a $10 \mathrm{sec}$ pulse of K60 as indicated by the arrow. (a) Representative single amperometric events triggered in cells infected with Hu/wt subunit $(n=43)$ or (b) Hu/S1898A $(n=42)$. (c) Cumulative distribution plot of spike number and analysis of peak amplitude induced in $\mathrm{Hu} / \mathrm{wt}$ - and $\mathrm{Hu} / \mathrm{S} 1898 \mathrm{~A}$-infected cells (inset) mean values for peak amplitude $n=1048, n=547$ events per data point, respectively. (d) Cumulative distribution plot of spike number and analysis of 50-90\% rise time detected in Hu/wt- and Hu/S1898A-infected cells. Data plotted similar fashion as in panel (c), mean values for 50-90\% rise time (inset). (e) Cumulative distribution plot of spike number and analysis of half-width of $\mathrm{Hu} /$ wt- and $\mathrm{Hu} / \mathrm{S} 1898 \mathrm{~A}$-infected cells; mean values for spike half-width (inset). (f) Cumulative distribution plot of spike number and analysis of mean charge in $\mathrm{Hu} / \mathrm{wt}$ - and Hu/S1898A-infected cells; mean values for spike mean charge (inset). (g) Cumulative distribution plot of foot number and analysis of foot amplitudes in Hu/wt- and Hu/S1898A-infected cells; mean values for foot amplitude (inset). (h) Cumulative distribution plot of foot number and analysis of foot width in Hu/wt- and Hu/S1898A-infected cells; mean values for foot width (inset). 
TABLE 1: The effect of forskolin on the rate and total catecholamine secretion. The rate of secretion was determined in cells infected with GFP, $\mathrm{Hu} / \mathrm{wt}$, the wt human $\alpha_{1} 1.2$ subunit, and $\mathrm{Hu} / \mathrm{S} 1898 \mathrm{~A}$, and the mutant $\alpha_{1} 1.2 / \mathrm{S} 1898 \mathrm{~A}$ subunit.

\begin{tabular}{|c|c|c|c|c|c|c|c|}
\hline \multirow{2}{*}{ Group } & \multirow{2}{*}{ \# Cells } & \multirow{2}{*}{ \# Spikes } & \multirow{2}{*}{$\begin{array}{l}\text { AVG } \\
\text { \# Spikes }\end{array}$} & \multicolumn{2}{|c|}{ Frequency } & \multicolumn{2}{|c|}{ Secretion } \\
\hline & & & & $\begin{array}{c}10-40 \mathrm{sec} \\
\text { (Spike/sec) }\end{array}$ & Fold & $\begin{array}{c}10-40 \mathrm{sec} \\
(\mathrm{pC})\end{array}$ & Fold \\
\hline Noninfected & 18 & 502 & $27 \pm 4.8$ & $\begin{array}{l}0.53 \pm 0.02 \\
R^{2}=0.995\end{array}$ & & $15.4 \pm 1.8$ & \\
\hline GFP & 49 & 1048 & $21.4 \pm 3.0$ & $\begin{array}{l}0.52 \pm 0.01 \\
R^{2}=0.989\end{array}$ & & $16 \pm 2.5$ & \\
\hline $\mathrm{GFP}+\mathrm{FSK}^{\mathrm{a}}$ & 21 & 693 & $33 \pm 3.2$ & $\begin{array}{l}0.79 \pm 0.03 \\
R^{2}=0.994\end{array}$ & 1.5 & $26 \pm 4.4^{*}$ & 1.6 \\
\hline $\mathrm{Hu} / \mathrm{wt}$ & 43 & 943 & $22 \pm 2.5$ & $\begin{array}{l}0.57 \pm 0.02 \\
R^{2}=0.989\end{array}$ & & $17 \pm 1.9$ & \\
\hline $\mathrm{Hu} / \mathrm{wt}+\mathrm{FSK}$ & 34 & 1052 & $30 \pm 4.9$ & $\begin{array}{l}0.86 \pm 0.03 \\
R^{2}=0.982\end{array}$ & 1.5 & $28 \pm 4.5^{*}$ & 1.6 \\
\hline $\mathrm{Hu} / \mathrm{S} 1898 \mathrm{~A}$ & 42 & 547 & $13 \pm 1.4$ & $\begin{array}{l}0.35 \pm 0.01 \\
R^{2}=0.995\end{array}$ & & $10 \pm 0.9$ & \\
\hline $\begin{array}{l}\mathrm{Hu} / \mathrm{S} 1898 \mathrm{~A} \\
+\mathrm{FSK}\end{array}$ & 40 & 953 & $23.8 \pm 3.5$ & $\begin{array}{l}0.46 \pm 0.01 \\
R^{2}=0.985\end{array}$ & 1.3 & $16 \pm 2.1^{*}$ & 1.6 \\
\hline
\end{tabular}

Cells were stimulated for $10 \mathrm{sec}$ by $60 \mathrm{mM} \mathrm{KCl}$. Amperometric currents were measured during time range of $10-40 \mathrm{sec}$, which includes the 10 sec K60 stimulation and a $20 \mathrm{sec}$ poststimulus period.

${ }^{\mathrm{a}} 1 \mu \mathrm{M}$ forskolin (FSK); ${ }^{*} P<0.05$.

(Figure 5(a)), $1 \mu \mathrm{M}$ forskolin when applied to GFP-infected cells increased the frequency of the amperometric events. The analysis of cumulative spikes showed an increase from $21 \pm 3$ to $33 \pm 3.1$ spikes/cell (Table 1 ) and a 1.5 -fold increase in the initial rate from $0.52 \pm 0.01$ to $0.79 \pm 0.03$ spike/sec (Figure 5(c) left). The increase in the frequency of the amperometric events induced by forskolin also led to a 1.6-fold increase in total catecholamine secretion, which was calculated as the total mean charge of spike area within the range of $10-40 \mathrm{sec}$ during and after stimulation (Figure 5(c) right; Table 1).

Next, we compared the effect of forskolin on secretion mediated by the $\mathrm{Hu} /$ wt or $\mathrm{Hu} / \mathrm{S} 1898 \mathrm{~A}$. Shown by representative amperometric traces, forskolin accelerated the rate of secretion in cells infected with either $\mathrm{Hu} /$ wt or $\mathrm{Hu} / \mathrm{S} 1898 \mathrm{~A}$ (Figure 6(a)). The increase in the frequency of the amperometric spikes induced by forskolin was quantified as described above (see Figure 2). In both the GFP- and Hu/wtinfected cells, the rate of secretion was increased 1.5-fold, and in the Hu/S1898A-infected cells 1.3-fold (Figures 6(a) and 6(b) and Table 1). Forskolin increased the total release of catecholamine to a similar extent (1.6-fold), in the GFP-, $\mathrm{Hu} /$ wt-, or Hu/S1898A-infected cells, as summarized in the bar graph (Figure 6(c)) and Table 1.

Forskolin induced a similar upregulation of release events mediated by the human $\mathrm{Hu} / \mathrm{wt}$ and the endogenous bovine channel (measured in cells infected with GFP). A smaller increase (1.3-fold compared to 1.5-fold) was observed in $\mathrm{Hu} /$ S1898A-infected cells.

3.6. The Effects of Forskolin on the Kinetics of the Amperometric Spikes and Foot. In spite of the increase in the frequency of secretion by forskolin, no effect on the kinetics of the individual amperometric spikes and prespikes (foot) was observed, as presented in Table SI of the supplementary material available online at doi:10.1155/2011/746482.

\section{Discussion}

4.1. The Contribution of S1898 to the Rate of Secretion in Chromaffin Cells. In bovine chromaffin cells membrane depolarization triggers catecholamine release primarily via the activation of the dihydropyridine-sensitive VGCC, known as the L-type channel. This was previously shown using selective DHP L-type channel blockers $[26,28]$. The activity of $\mathrm{Ca}_{\mathrm{V}} 1.2$ like other VGCC is further modulated by phosphorylation $[2,4]$.

Phosphorylation of the L-type channel or $\mathrm{Cav}_{\mathrm{V}} 1.2$ by protein Kinase A (PKA) and protein kinase C (PKC) further modulates the kinetics of the channel [4]. Biochemical studies in the heart and in neuronal cells have shown that the distal C-terminal tail of the $\alpha_{1} 1.2$ subunit is phosphorylated by PKA on serine 1928 (S1928) [14-17]. This consensus phosphorylation site corresponds to $\mathrm{S} 1898$ in the human $\mathrm{Ca}_{V} 1.2$, and here we have tested whether this site at the human pore forming $\alpha_{1} 1.2$ subunit contributes to the regulation of catecholamine release in bovine chromaffin cells.

At first we confirmed that bovine chromaffin cells infected with pSFV vector containing GFP retained their sensitivity to nifedipine. Secretion of CA that was monitored using carbon fiber amperometry was reduced by more than $85 \%$.

Both the human wt $\alpha_{1} 1.2(\mathrm{Hu} / \mathrm{wt})$ and the $\alpha_{1} 1.2 / \mathrm{S} 1898 \mathrm{~A}$ (Hu/S1898A) subunits, which are equally expressed and targeted to the cell membrane, were introduced into chromaffin cells via Semliki forest viral infection. The two channel 

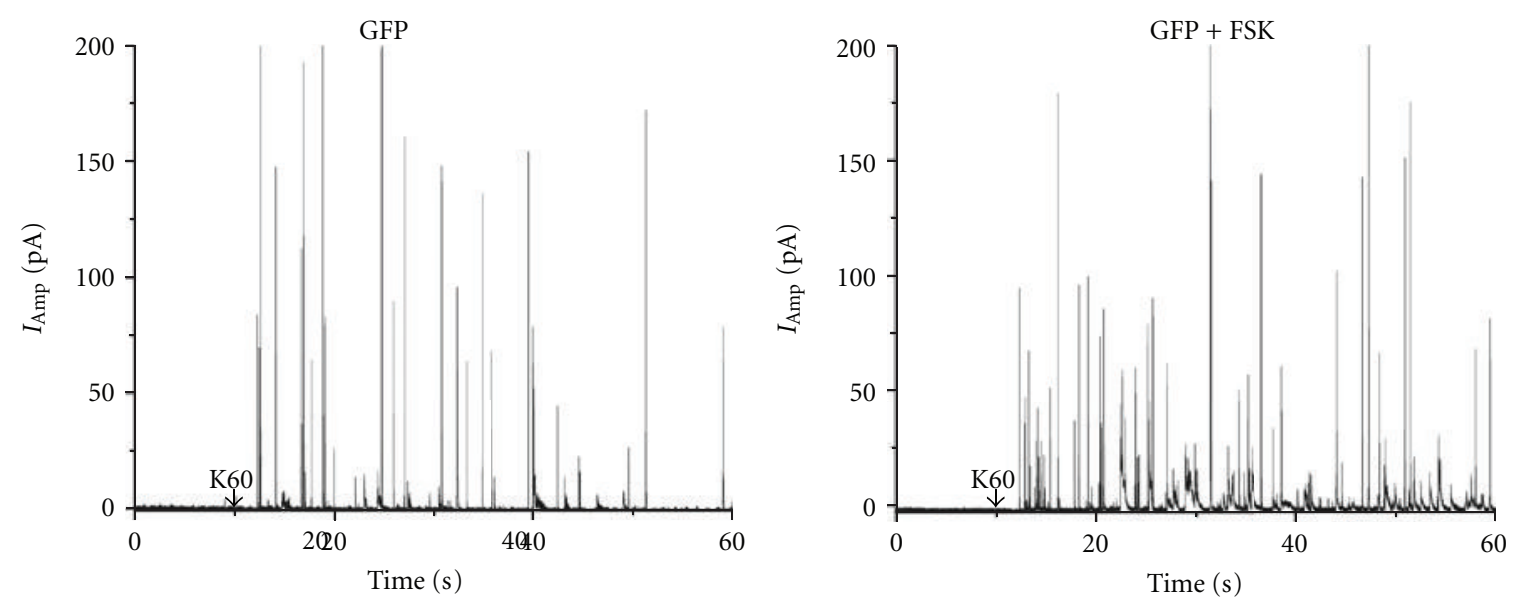

(a)
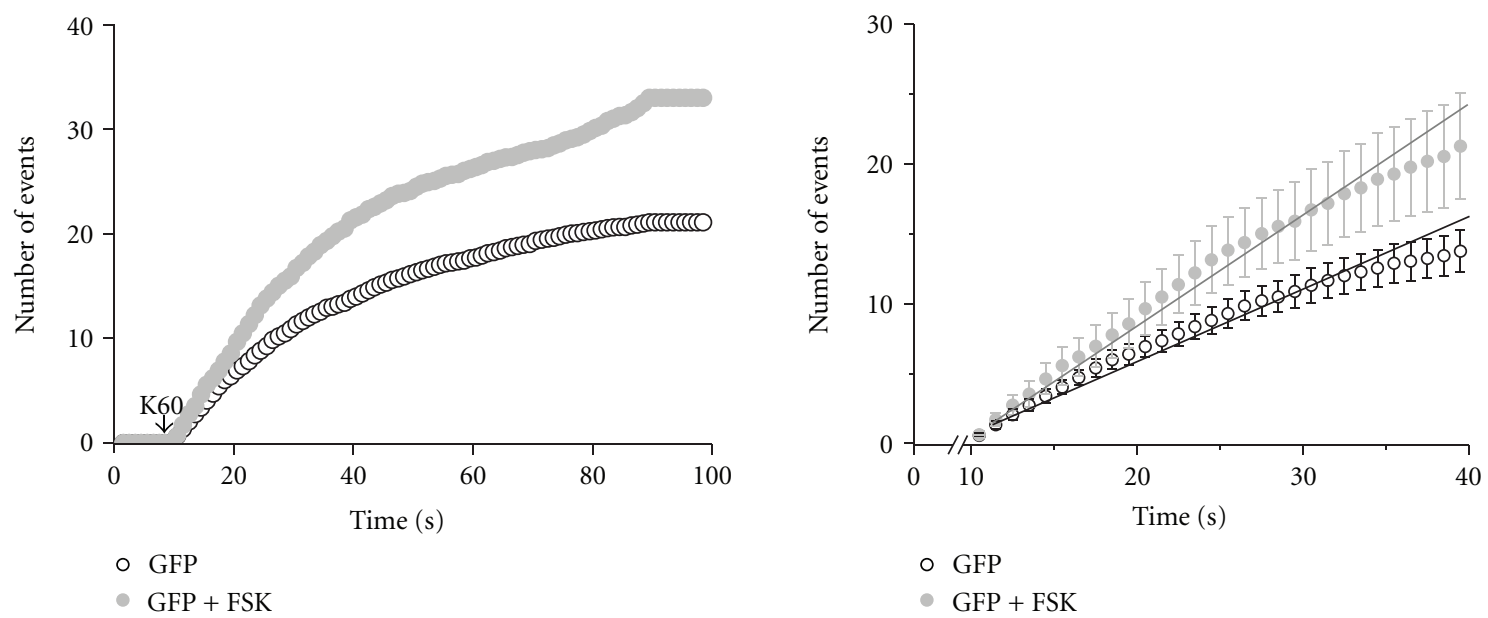

(b)
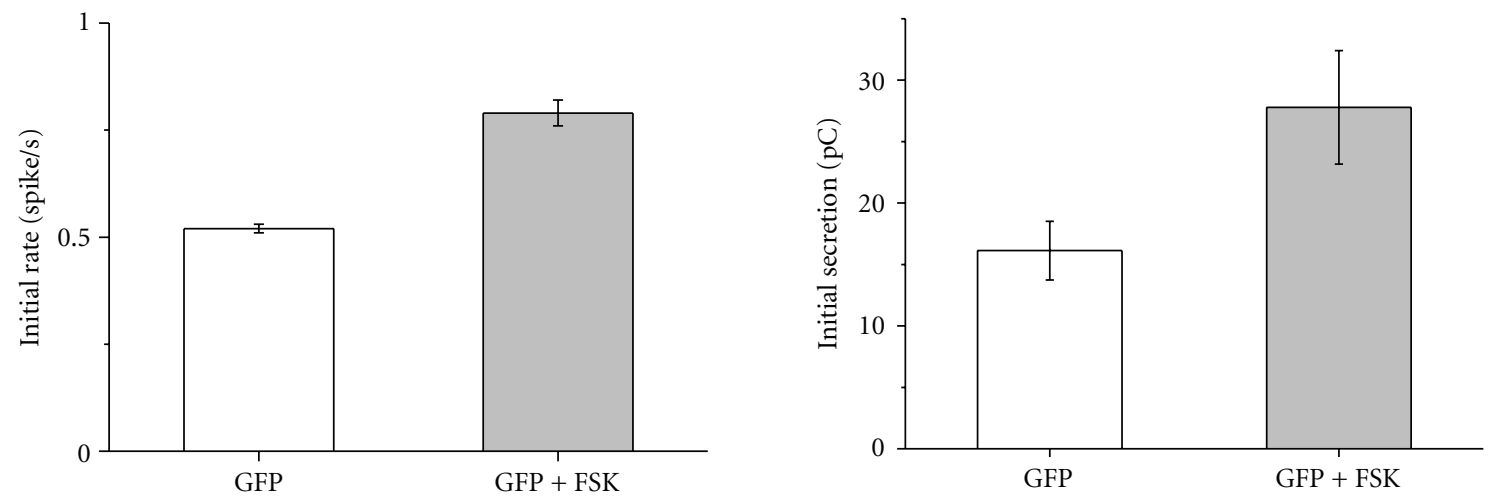

(c)

FIGURE 5: The effect of forskolin on GFP-infected chromaffin cells. Amperometry currents were elicited by a 10 sec puff of $60 \mathrm{mM} \mathrm{KCl}$ (K60) in GFP-infected cells in the presence of $1 \mu \mathrm{M}$ forskolin, as indicated by the arrow. (a) Representative single amperometric events of GFPinfected cells with $(n=21)$ or without forskolin $(n=49)$. (b) The cumulative number of events per cell averaged for GFP-infected cells with or without forskolin was plotted versus time (left). An expanded view of the initial cumulative spike counts plotted versus time (right). (c) The initial rate of secretion calculated from the linearization of the cumulative averaged spike count (left). Means were calculated for individual cells as an average of more than 500 spikes; see Table 1 . The total amount of catecholamine secreted was quantified by averaging of the total mean charge. Summation of spike areas in cells infected with GFP during time range of 10-40 sec, which includes the 10 sec K60 stimulation and a $20 \mathrm{sec}$ poststimulus period (right); ${ }^{*} P<0.05$. 

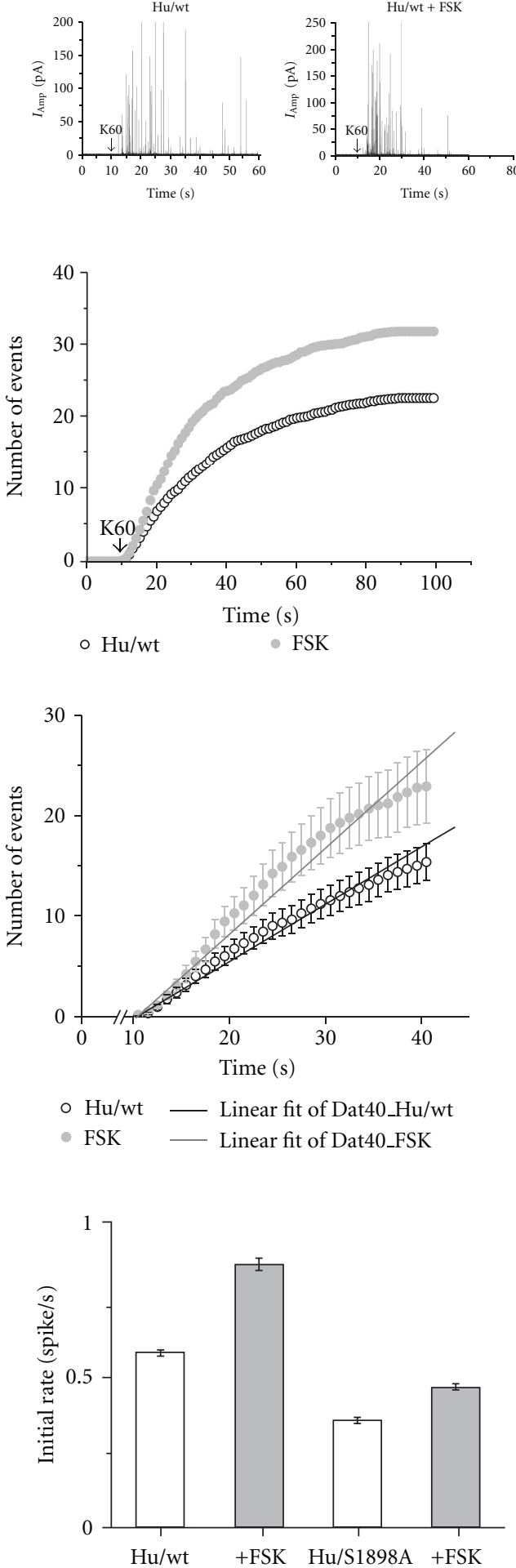
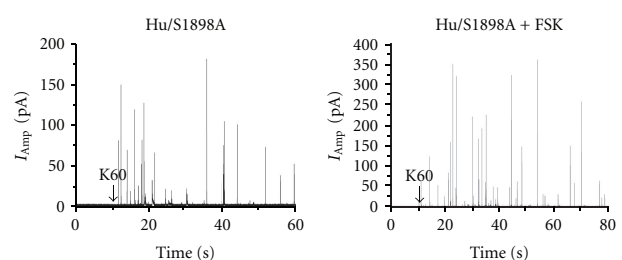

(a)
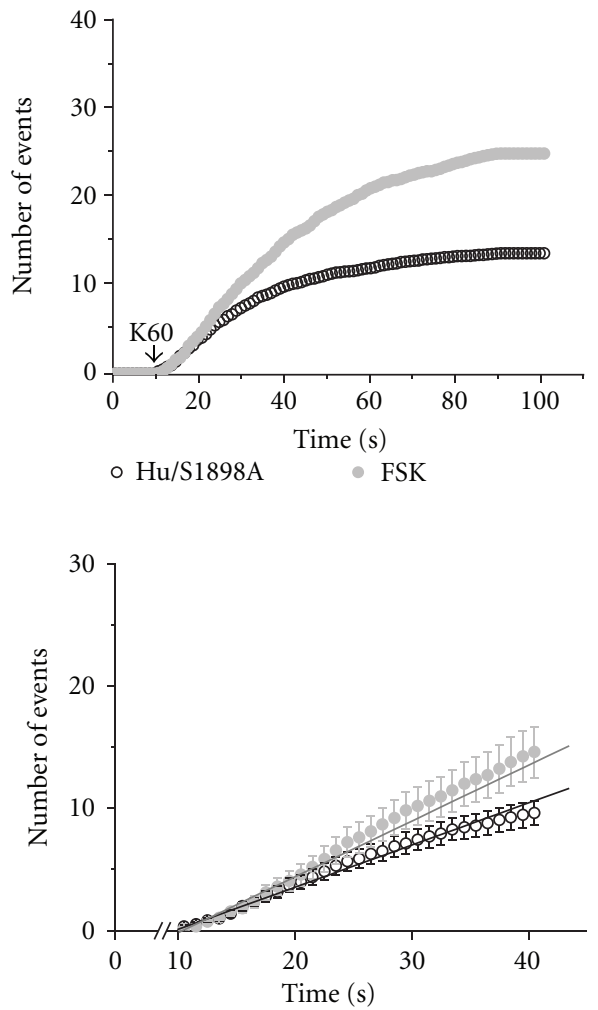

$\begin{array}{ll}\text { - } \mathrm{Hu} / \mathrm{S} 1898 \mathrm{~A} & - \text { Linear fit of Dat40_Hu/S1898A } \\ \text { - FSK } & \text { Linear fit of Dat40_FSK }\end{array}$

(b)

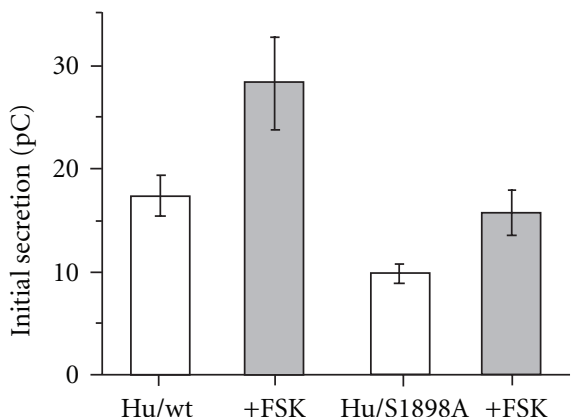

(c)

Figure 6: Forskolin accelerates secretion to the same extent in Hu/wt- and Hu/S1898A-infected cells. Amperometry currents were elicited by a $10 \mathrm{sec}$ puff of $60 \mathrm{mM} \mathrm{KCl} \mathrm{(K60)} \mathrm{as} \mathrm{indicated} \mathrm{by} \mathrm{the} \mathrm{arrow,} \mathrm{in} \mathrm{chromaffin} \mathrm{cells} \mathrm{infected} \mathrm{with} \mathrm{pSFV} \mathrm{containing} \mathrm{Hu/wt} \mathrm{(left)} \mathrm{or} \mathrm{Hu/S1898A}$ (right) in the presence of $1 \mu \mathrm{M}$ forskolin and $5 \mu \mathrm{M}$ nifedipine. (a) Representative single amperometric events in Hu/wt or Hu/S1898A infected cells, with and without forskolin. (b) The cumulative number of events per cell averaged for Hu/wt- and Hu/S1898A-infected cells $(n=49$ and $n=42)$, with or without forskolin $(n=43$ and $n=40)$, was plotted versus time. An expanded view of the initial cumulative spike counts plotted versus time (lower). (c) The initial rates of secretion were calculated from the linearization of the cumulative averaged spike count (left). Means were calculated for individual cells as an average from more than 500 spikes; see Table SI. Total amount of catecholamine secreted was quantified by averaging of the total mean charge. Summation of spike areas in cells infected with Hu/wt (empty columns) or $\mathrm{Hu} / \mathrm{S} 1898 \mathrm{~A}$ (gray columns) during time range of $10-40 \mathrm{sec}($ right $) ;{ }^{*} \mathrm{P}<0.05$. 
subunits each harbored an additional mutation that rendered them nifedipine insensitive. Secretion in the infected cells was carried out in the presence of nifedipine, which enabled the functional discrimination of L-type-mediated secretion contributed by exogenously expressed human channels from that of native bovine $\mathrm{Ca}^{2+}$ channels. The frequency of secretion and the total catecholamine released that was mediated by the endogenous bovine channel was similar to that of the human $\alpha_{1} 1.2(\mathrm{Hu} / \mathrm{wt})$ channel. Also the spike parameters and the prespike (foot) parameters were indistinguishable.

4.2. Forskolin Elevated Depolarization-Evoked Secretion Independently of S1898. Protein microsequencing of phosphopeptide mapping confirmed that phosphorylation occurs at a PKA site, at serine 1928 near the C-terminus of cardiac $\alpha_{1} 1.2$ [14]. Based on these results it was suggested that the single PKA consensus site S1928 is involved in the $\beta$-adrenergic receptor modulation of channel activity.

Forskolin is known to activate adenylyl cyclase, which by producing cAMP and activating PKA, leads to the phosphorylation of the $\alpha 1$ subunits of the L-type channel thereby, upregulating its activity. It was previously shown that forskolin elevation of cAMP could be fully accounted for by the activation of the $\beta$-adrenergic receptor $[25,42,43]$. Using forskolin, we tested the contribution of the human $\alpha_{1} 1.2$ subunit to secretion by mutating Ser1898 to Ala, the site that corresponds to the $\mathrm{S} 1928$ in rabbit cardiac $\alpha_{1} 1.2$ subunit.

The modulation of secretion by the PKA activation pathway was tested by forskolin that was applied to chromaffin cells infected with the $\mathrm{Hu} /$ wt or $\mathrm{Hu} / \mathrm{S} 1898 \mathrm{~A}$ subunits.

The direct activation of adenylyl-cyclase by forskolin in GFP-infected and in the Hu/wt-infected cells led to a similar fold increase in the rate of depolarization-evoked secretion and total catecholamine release. These results suggest that the human $\alpha_{1}$ subunit was most likely phosphorylated by PKA to the same extent as the endogenous $\alpha_{1}$ subunit.

On the other hand, the positive impact of forskolin on the rate of secretion was slightly lower in cells infected with the $\mathrm{Hu} / \mathrm{S} 1898 \mathrm{~A}$ subunit. These results suggest that forskolin upregulates evoked secretion only marginally via S1898.

These results are in agreement with others [23] who have demonstrated that the phosphorylation of S1928 in the rabbit channel accounts only partially $(\sim 20-30 \%)$ for the $\beta$ adrenergic regulation of calcium currents in cardiomyocytes [17]. Furthermore, in $\mathrm{Ca}_{\mathrm{V}} 1.2^{\mathrm{S} 1928-129 \mathrm{~B} 6 \mathrm{~F} 2}$ mice, no detectable differences in heart rate were detected compared to control animals during isoproterenol infusion [25]. It is predicted that forskolin mediates phosphorylation through additional site(s) either at the $\alpha_{1} 1.2$ subunit or in other channel subunits $[22,44]$ and only marginally through S1898. Previous studies have also shown that phosphorylation of this site involves PKC [24].

In our studies, both the $\mathrm{Hu} / \mathrm{wt}$ and the $\mathrm{Hu} / \mathrm{S} 1898 \mathrm{~A}$ channel subunits mediate faster rate of secretion by forskolin. Sincez forskolin modified secretion largely independently of the presence of Ser or Ala at position 1898, we concluded that the cAMP-dependent PKA has contributed to the modulation of secretion via other selective sites [25]. Other studies have proposed that the cardiac L-type $\mathrm{Ca}^{2+}$ channels are phosphorylated in basal state by high levels of PKA phosphorylation, while dephosphorylation reduces their activity $[19,45]$.

In summary, our results show that mutating S1898 hardly affected the forskolin-induced increase in depolarizationevoked secretion in the neuroendocrine cells. Given that a similar forskolin-mediated increase in the rate of secretion was observed in cells infected with $\mathrm{Hu} /$ wt and $\mathrm{Hu} / \mathrm{S} 1898 \mathrm{~A}$ mutant, our results indicate that other phosphorylation sites either at the L-type channel auxiliary subunits or other proteins of the secretory apparatus are involved in the upregulation of depolarization-evoked secretion in chromaffin cells.

\section{Acknowledgments}

The authors thank Michael Trus for commenting and editing the paper and Khaled Zoabe for providing the adrenal glands. This paper is supported by the Betty Feffer foundation for D.A.

\section{References}

[1] H. Reuter, "Calcium channel modulation by $\beta$-adrenergic neurotransmitters in the heart," Experientia, vol. 43, no. 1112, pp. 1173-1175, 1987.

[2] A. C. Dolphin, "L-type calcium channel modulation," Advances in Second Messenger and Phosphoprotein Research, vol. 33, pp. 153-177, 1999.

[3] K. Nunoki, V. Florio, and W. A. Catterall, "Activation of purified calcium channels by stoichiometric protein phosphorylation," Proceedings of the National Academy of Sciences of the United States of America, vol. 86, no. 17, pp. 6816-6820, 1989.

[4] W. A. Catterall, "Structure and regulation of voltage-gated $\mathrm{Ca}^{2+}$ channels," Annual Review of Cell and Developmental Biology, vol. 16, pp. 521-555, 2000.

[5] B. P. Bean, M. C. Nowycky, and R. W. Tsien, " $\beta$-Adrenergic modulation of calcium channels in frog ventricular heart cells," Nature, vol. 307, no. 5949, pp. 371-375, 1984.

[6] T. F. Mcdonald, S. Pelzer, W. Trautwein, and D. J. Pelzer, "Regulation and modulation of calcium channels in cardiac, skeletal, and smooth muscle cells," Physiological Reviews, vol. 74, no. 2, pp. 365-507, 1994.

[7] C. A. Artalejo, M. K. Dahmer, R. L. Perlman, and A. P. Fox, "Two types of $\mathrm{Ca}^{2+}$ currents are found in bovine chromaffin cells: facilitation is due to the recruitment of one type," Journal of Physiology, vol. 432, pp. 681-707, 1991.

[8] C. R. Artalejo, S. Rossie, R. L. Perlman, and A. P. Fox, "Voltagedependent phosphorylation may recruit $\mathrm{Ca}^{2+}$ current facilitation in chromaffin cells," Nature, vol. 358, no. 6381, pp. 63-66, 1992.

[9] E. T. Kavalali, K. S. Hwang, and M. R. Plummer, "cAMPdependent enhancement of dihydropyridine-sensitive calcium channel availability in hippocampal neurons," Journal of Neuroscience, vol. 17, no. 14, pp. 5334-5348, 1997.

[10] A. Sculptoreanu, E. Rotman, M. Takahashi, T. Scheuer, and W. A. Catterall, "Voltage-dependent potentiation of the activity of cardiac L-type calcium channel $\alpha 1$ subunits due to phosphorylation by cAMP-dependent protein kinase," Proceedings of the National Academy of Sciences of the United States of America, vol. 90, no. 21, pp. 10135-10139, 1993. 
[11] D. T. Yue, S. Herzig, and E. Marban, " $\beta$-Adrenergic stimulation of calcium channels occurs by potentiation of highactivity gating modes," Proceedings of the National Academy of Sciences of the United States of America, vol. 87, no. 2, pp. 753757, 1990

[12] D. M. Bers, "Cardiac excitation-contraction coupling," Nature, vol. 415, no. 6868, pp. 198-205, 2002.

[13] M. A. Davare, V. Avdonin, D. D. Hall et al., "A $\beta 2$ adrenergic receptor signaling complex assembled with the $\mathrm{Ca}^{2+}$ channel $\mathrm{Ca}_{\mathrm{v}}$ 1.2," Science, vol. 293, no. 5527, pp. 98-101, 2001.

[14] K. S. De Jongh, B. J. Murphy, A. A. Colvin, J. W. Hell, M. Takahashi, and W. A. Catterall, "Specific phosphorylation of a site in the full-length form of the $\alpha 1$ subunit of the cardiac L-type calcium channel by adenosine $3^{\prime}-5^{\prime}$-cyclic monophosphate-dependent protein kinase," Biochemistry, vol. 35, no. 32, pp. 10392-10402, 1996.

[15] J. Mitterdorfer, M. Froschmayr, M. Grabner, F. F. Moebius, H. Glossmann, and J. Striessnig, "Identification of PK-A phosphorylation sites in the carboxyl terminus of L-type calcium channel $\alpha 1$ subunits," Biochemistry, vol. 35, no. 29, pp. 9400-9406, 1996.

[16] P. C. Gray, J. D. Scott, and W. A. Catterall, "Regulation of ion channels by cAMP-dependent protein kinase and A-kinase anchoring proteins," Current Opinion in Neurobiology, vol. 8, no. 3, pp. 330-334, 1998.

[17] J. T. Hulme, R. E. Westenforoek, T. Scheuer, and W. A. Catterall, "Phosphorylation of serine 1928 in the distal Cterminal domain of cardiac $\mathrm{Ca}_{\mathrm{v}} 1.2$ channels during $\beta 1$ adrenergic regulation," Proceedings of the National Academy of Sciences of the United States of America, vol. 103, no. 44, pp. 16574-16579, 2006.

[18] J. W. Hell, C. T. Yokoyama, S. T. Wong, C. Warner, T. P. Snutch, and W. A. Catterall, "Differential phosphorylation of two size forms of the neuronal class C L- type calcium channel $\alpha 1$ subunit," The Journal of Biological Chemistry, vol. 268, no. 26, pp. 19451-19457, 1993.

[19] T. Perets, Y. Blumenstein, E. Shistik, I. Lotan, and N. Dascal, "A potential site of functional modulation by protein kinase A in the cardiac $\mathrm{Ca}^{2+}$ channel $\alpha 1 \mathrm{c}$ subunit," FEBS Letters, vol. 384, no. 2, pp. 189-192, 1996.

[20] M. A. Davare and J. W. Hell, "Increased phosphorylation of the neuronal L-type $\mathrm{Ca}^{2+}$ channel $\mathrm{Ca}_{\mathrm{v}} 1.2$ during aging," Proceedings of the National Academy of Sciences of the United States of America, vol. 100, no. 26, pp. 16018-16023, 2003.

[21] D. D. Hall, J. A. Feekes, A. S. Arachchige Don et al., "Binding of protein phosphatase $2 \mathrm{~A}$ to the L-type calcium channel $\mathrm{Ca}_{\mathrm{v}} 1.2$ next to Ser1928, its main PKA site, is critical for Ser1928 dephosphorylation," Biochemistry, vol. 45, no. 10, pp. $3448-$ 3459, 2006.

[22] M. Bünemann, B. L. Gerhardstein, T. Gao, and M. M. Hosey, "Functional regulation of L-type calcium channels via protein kinase A- mediated phosphorylation of the $\beta 2$ subunit," The Journal of Biological Chemistry, vol. 274, no. 48, pp. 3385133854, 1999.

[23] A. N. Ganesan, C. Maack, D. C. Johns, A. Sidor, and B. O'Rourke, “ $\beta$-Adrenergic stimulation of L-type $\mathrm{Ca}^{2+}$ channels in cardiac myocytes requires the distal carboxyl terminus of $\alpha 1 \mathrm{C}$ but not serine 1928," Circulation Research, vol. 98, no. 2, pp. e11-e18, 2006.

[24] L. Yang, G. Liu, S. I. Zakharov et al., "Ser1928 is a common site for $\mathrm{Ca}_{\mathrm{v}} 1.2$ phosphorylation by protein kinase C isoforms," The Journal of Biological Chemistry, vol. 280, no. 1, pp. 207214, 2005.
[25] T. Lemke, A. Welling, C. J. Christel et al., "Unchanged $\beta$-adrenergic stimulation of cardiac L-type calcium channels in $\mathrm{Ca}_{\mathrm{v}}$ 1.2 phosphorylation site S1928A mutant mice," The Journal of Biological Chemistry, vol. 283, no. 50, pp. 34738-34744, 2008.

[26] V. Cena, G. P. Nicolas, P. Sanchez Garcia, S. M. Kirpekar, and A. G. Garcia, "Pharmacological dissection of receptorassociated and voltage-sensitive ionic channels involved in catecholamine release," Neuroscience, vol. 10, no. 4, pp. 14551462, 1983.

[27] B. Avidor, T. Avidor, L. Schwartz, K. S. De Jongh, and D. Atlas, "Cardiac L-type $\mathrm{Ca}^{2+}$ channel triggers transmitter release in PC12 cells," FEBS Letters, vol. 342, no. 2, pp. 209-213, 1994.

[28] Y. Hagalili, N. Bachnoff, and D. Atlas, "The Voltage-gated Ca ${ }^{2+}$ channel is the $\mathrm{Ca}^{2+}$ sensor protein of secretion," Biochemistry, vol. 47, no. 52, pp. 13822-13830, 2008.

[29] O. Wiser, M. K. Bennett, and D. Atlas, "Functional interaction of syntaxin and SNAP-25 with voltage-sensitive L- and N-type $\mathrm{Ca}^{2+}$ channels," EMBO Journal, vol. 15, no. 16, pp. 4100-4110, 1996.

[30] O. Wiser, M. Trus, A. Hernández et al., "The voltage sensitive Lc-type $\mathrm{Ca}^{2+}$ channel is functionally coupled to the exocytotic machinery," Proceedings of the National Academy of Sciences of the United States of America, vol. 96, no. 1, pp. 248-253, 1999.

[31] M. Trus, R. F. Corkey, R. Nesher et al., "The L-type voltagegated $\mathrm{Ca}^{2+}$ channel is the $\mathrm{Ca}^{2+}$ sensor protein of stimulussecretion coupling in pancreatic beta cells," Biochemistry, vol. 46, no. 50, pp. 14461-14467, 2007.

[32] D. Atlas, "Functional and physical coupling of voltagesensitive calcium channels with exocytotic proteins: ramifications for the secretion mechanism," Journal of Neurochemistry, vol. 77, no. 4, pp. 972-985, 2001.

[33] R. Cohen, B. M. Schmitt, and D. Atlas, "Molecular identification and reconstitution of depolarization-induced exocytosis monitored by membrane capacitance," Biophysical Journal, vol. 89, no. 6, pp. 4364-4373, 2005.

[34] I. Lerner, M. Trus, R. Cohen, O. Yizhar, I. Nussinovitch, and D. Atlas, "Ion interaction at the pore of Lc-type $\mathrm{Ca}^{2+}$ channel is sufficient to mediate depolarization-induced exocytosis," Journal of Neurochemistry, vol. 97, no. 1, pp. 116-127, 2006.

[35] R. Cohen, B. M. Schmitt, and D. Atlas, "Reconstitution of depolarization and $\mathrm{Ca}^{2+}$-evoked secretion in xenopus oocytes monitored by membrane capacitance," Methods in Molecular Biology, vol. 440, pp. 269-282, 2008.

[36] R. H. Chow, L. Von Ruden, and E. Neher, "Delay in vesicle fusion revealed by electrochemical monitoring of single secretory events in adrenal chromaffin cells," Nature, vol. 356, no. 6364, pp. 60-63, 1992.

[37] U. Ashery, A. Betz, X. Tao, N. Brose, and J. Rettig, "An efficient method for infection of adrenal chromaffin cells using the Semliki Forest virus gene expression system," European Journal of Cell Biology, vol. 78, no. 8, pp. 525-532, 1999.

[38] R. M. Wightman, J. A. Jankowski, R. T. Kennedy et al., “Temporally resolved catecholamine spikes correspond to single vesicle release from individual chromaffin cells," Proceedings of the National Academy of Sciences of the United States of America, vol. 88, no. 23, pp. 10754-10758, 1991.

[39] M. He, I. Bodi, G. Mikala, and A. Schwartz, "Motif III S5 of L-type calcium channels is involved in the dihydropyridine binding site. A combined radioligand binding and electrophysiological study," The Journal of Biological Chemistry, vol. 272, no. 5, pp. 2629-2633, 1997.

[40] T. L. Colliver, E. J. Hess, E. N. Pothos, D. Sulzer, and A. G. Ewing, "Quantitative and statistical analysis of the shape of 
amperometric spikes recorded from two populations of cells," Journal of Neurochemistry, vol. 74, no. 3, pp. 1086-1097, 2000.

[41] C. T. Wang, R. Grishanin, C. A. Earles et al., "Synaptotagmin modulation of fusion pore kinetics in regulated exocytosis of dense-core vesicles," Science, vol. 294, no. 5544, pp. 1111$1115,2001$.

[42] A. Yatani, J. Codina, Y. Imoto, J. Reeves, L. Birnbaumer, and A. M. Brown, "A G protein directly regulates mammalian cardiac calcium channels," Science, vol. 238, no. 4831, pp. 1288-1292, 1987.

[43] H. C. Hartzell, P. F. Mery, R. Fischmeister, and G. Szabo, "Sympathetic regulation of cardiac calcium current is due exclusively to cAMP-dependent phosphorylation," Nature, vol. 351, no. 6327, pp. 573-576, 1991.

[44] H. Haase, J. Alvarez, D. Petzhold et al., "Ahnak is critical for cardiac $\mathrm{Ca}(\mathrm{v}) 1.2$ calcium channel function and its $\beta$ adrenergic regulation," FASEB Journal, vol. 19, no. 14, pp. 1969-1977, 2005.

[45] D. Singer-Lahat, I. Lotan, M. Biel, V. Flockerzi, F. Hofmann, and N. Dascal, "Cardiac calcium channels expressed in xenopus oocytes are modulated by dephosphorylation but not by cAMP-Dependent phosphorylation," Receptors and Channels, vol. 2, no. 3, pp. 215-226, 1994. 


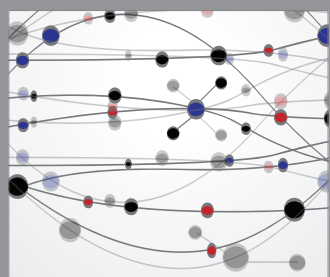

The Scientific World Journal
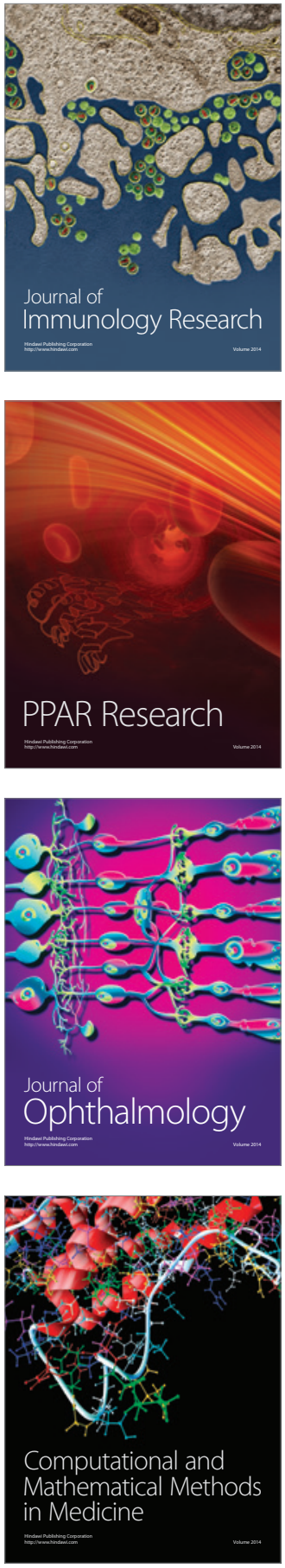

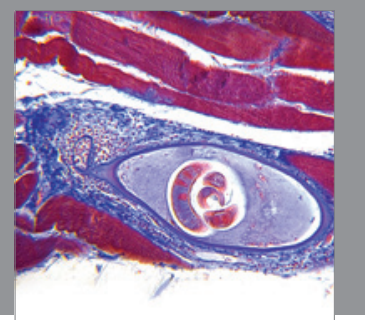

Gastroenterology

Research and Practice
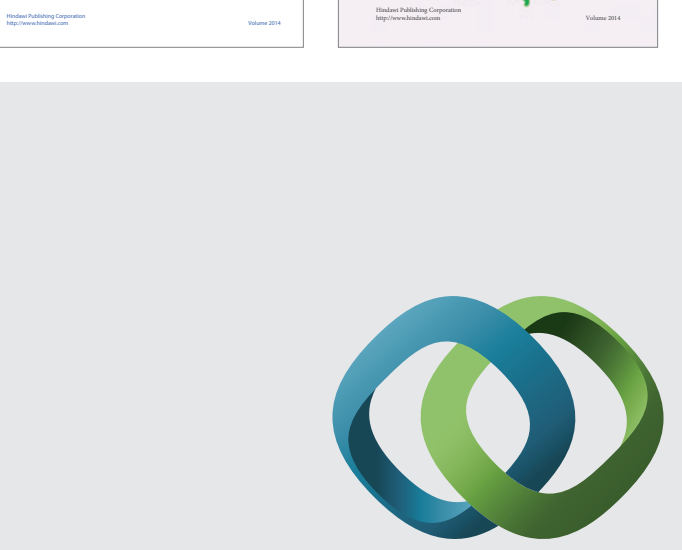

\section{Hindawi}

Submit your manuscripts at

http://www.hindawi.com
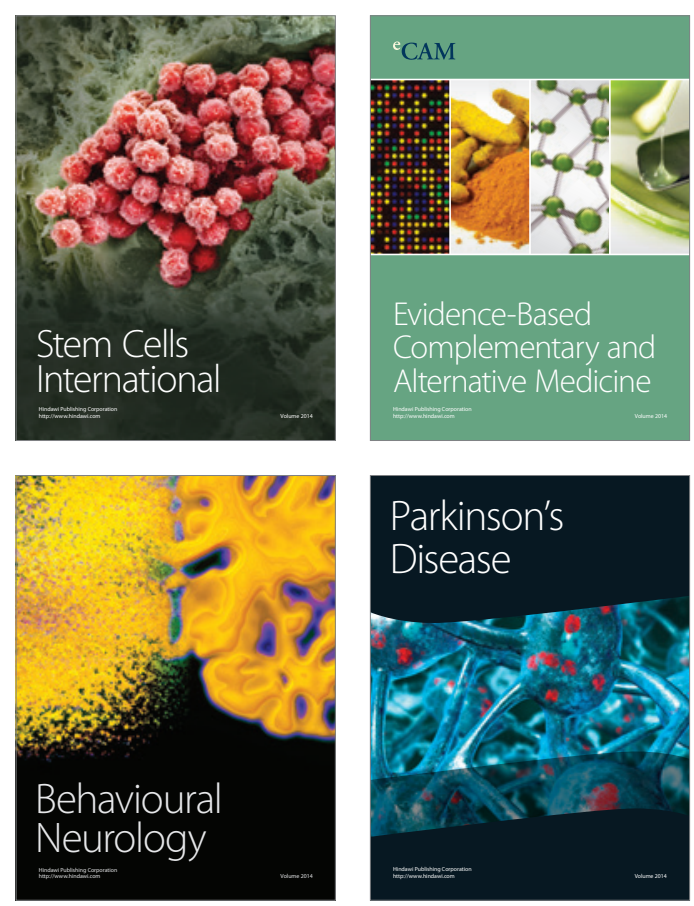

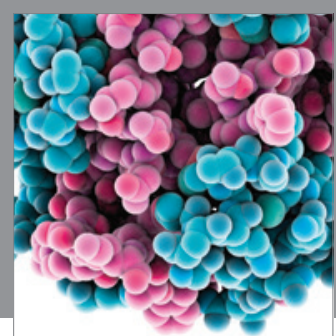

Journal of
Diabetes Research

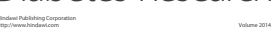

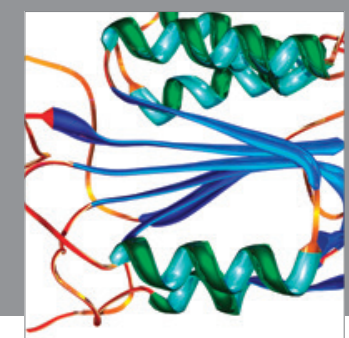

Disease Markers
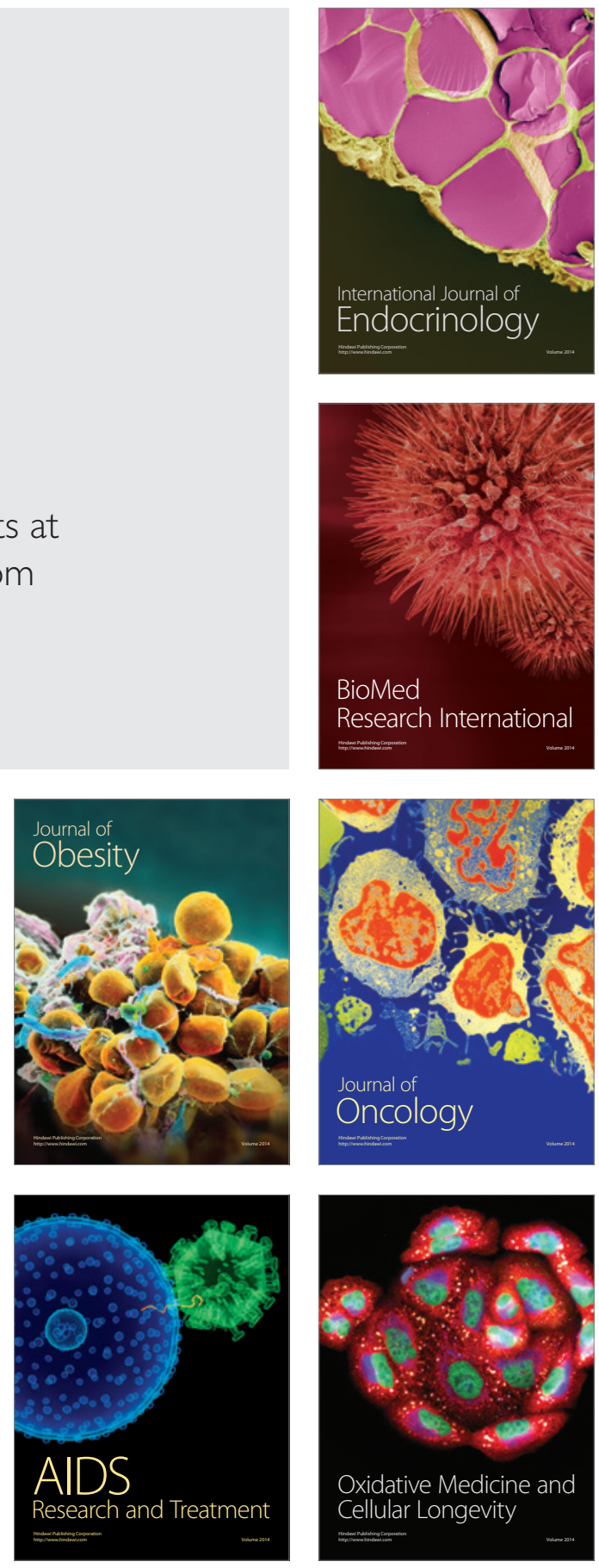